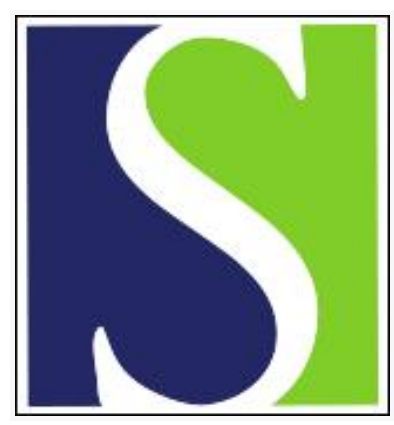

Scand J Work Environ Health 1991;17(1):53-59

https://doi.org/10.5271/sjweh.1734

Issue date: Feb 1991

Pulmonary effects of polyvinyl chloride dust exposure on compounding workers.

by Ng TP, Lee HS, Low YM, Phoon WH, Ng YL

Affiliation: Department of Community, Occupational and Family Medicine, National University of Singapore.

This article in PubMed: www.ncbi.nlm.nih.gov/pubmed/2047807

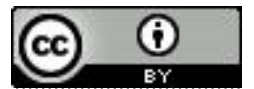




\title{
Pulmonary effects of polyvinyl chloride dust exposure on compounding workers
}

\author{
by Tze Pin Ng, FACOM, ${ }^{1}$ Hock Siang Lee, MSc $(\mathrm{OM},)^{2}$ Yong Meng Low, FRCR, ${ }^{3}$ \\ Wai Hoong Phoon, FFOM, ${ }^{2}$ Yuen Ling $\mathrm{Ng}$, Dip(FCT ${ }^{1}$
}

\begin{abstract}
NG TP, LEE HS, LOW YM, PHOON WH, NG YL. Pulmonary effects of polyvinyl chloride dust exposure on compounding workers. Scand J Work Environ Health 1991;17;53-9. Spirometry, chest radiography, environmental measurements, and a questionnaire on respiratory symptoms were used to evaluate the effects of exposure to polyvinyl chloride (PVC) dust on 171 Chinese and Malay PVC compounding workers in comparison with an unexposed reference group. Workers with high cumulative PVC dust exposure had a lower forced expiratory volume in $1 \mathrm{~s}$ and forced vital capacity, and a higher prevalence of radiological profusion of small opacities. Wheezing or chest tightness was also significantly more frequent in this group. Unlike previous studies, the PVC compounding workers in this study were exposed to only negligible amounts, if any, of vinyl chloride monomer or thermal degradation products of PVC such as hydrogen chloride, phosgene, or chlorine. The conclusion was drawn that a low grade of pneumoconiosis and a small degree of lung function impairment is associated with PVC dust exposure. Reversible airways obstruction is also likely and warrants further investigation.
\end{abstract}

Key terms: radiological profusion, spirometry, symptoms.

In 1970, Szende et al (1) first described radiological and histopathological evidence of a moderately diffuse fibrosis with granulomatous reaction in a worker exposed to PVC dust. Since then, several epidemiologic studies have investigated the pulmonary effects of occupational exposure to vinyl chloride monomer (VCM) and polyvinyl chloride (PVC). These studies have shown an increased prevalence of radiological, lung function, or subjective abnormalities (2-9). It would appear, however, that, in many of the earlier studies, control of possible biases or confounding was less than adequate because of the lack of appropriate reference groups, failure to take into account the influences of age or cigarette smoking properly, or the absence of standardized procedures in radiographic reading such as the use of standard radiographs of the International Labour Office (ILO) or multiple readers blind to the exposure status of the subjects. Several studies have also provided conflicting evidence for lung function impairment $(4,6,7)$.

It is also difficult to be certain that the pulmonary abnormalities reported in these studies were entirely due to exposure to PVC dust alone, since combined exposures to VCM and other air contaminants were known to be present. Most previous studies have investigated only vinyl chloride polymerization workers, who were exposed to both PVC dust and VCM (2-6).

1 Department of Community, Occupational and Family Medicine, National University of Singapore.

2 Industrial Health Department, Ministry of Labour, Singapore.

3 Singapore Anti-Tuberculosis Association.

Reprint requests to: Dr Ng Tze Pin, Department of Community, Occupational and Family Medicine, National University of Singapore, Lower Kent Ridge, Singapore 0511.
VCM has been reported to cause pulmonary fibrosis in animals (10), and PVC dust exposure among workers has been shown to induce less severe respiratory abnormalities than combined exposure to PVC and VCM (3).

PVC fabrication workers have also been studied (7-9), but these included other process workers, such as in calendering, laminating, or extruding, with potential exposure to thermal degradation products, solvents, and possibly additives known to cause acute bronchial reaction.

No previous investigation has studied a group of workers exposed almost exclusively to PVC dust. We have conducted a study of one such group, namely, PVC compounding workers, and present the results of the radiological, lung function, and symptoms evaluation in this report.

\section{Materials and methods}

\section{Manufacturing processes}

The study was conducted in three factories which produced PVC pellets which were then supplied to user industries for fabrication into other PVC products. The manufacturing processes were similar in all the factories, and no other processes were in operation except in one factory, where the pellets were fabricated into PVC rails in a separate building $100 \mathrm{~m}$ away. The bulk of the raw material, constituting more than $90 \%$ by weight, was PVC resin powder, which was compounded with other chemicals such as plasticizers, stabilizers, and pigments in semiautomated processes at temperatures not exceeding $170^{\circ} \mathrm{C}$. The most visibly dusty jobs in the factories were performed by 
mixers, who opened bags of the dry powdered materials and tipped them into hoppers. Other workers with less PVC dust exposure were employed as packers/ weighers, forklift drivers, storagemen, machine operators, fitters, electricians, material testers, cleaners, and so forth (table 1).

\section{Environmental assessment}

Current personal exposure to respirable PVC dust was measured for 10 job titles in each factory. A total of 56 personal samples of respirable $\mathrm{PVC}$ dust from the breathing zone of the workers was collected over sampling periods of about $4 \mathrm{~h}$ at the same time of the day on cellulose ester membrane filters with a diameter of $37 \mathrm{~mm}$ and a pore size of $8.0 \mu \mathrm{m}$. Personal dust sampling equipment (SKC Inc) was used at a flow rate of $2.01 / \mathrm{min}$. The job-specific exposures are summarized in table 1 .

Table 1. Dust concentrations in the three PVC factories by job title.

\begin{tabular}{lccc}
\hline Job title & $\begin{array}{c}\text { Number of } \\
\text { samples }\end{array}$ & $\begin{array}{c}\text { Mean } \\
\left(\mathrm{mg} / \mathrm{m}^{3}\right)\end{array}$ & $\begin{array}{c}\text { Range } \\
\left(\mathrm{mg} / \mathrm{m}^{3}\right)\end{array}$ \\
\hline Mixers & 21 & 1.55 & $0.21-2.90$ \\
Foremen & 3 & 0.42 & $0.38-0.70$ \\
Cleaner & 1 & 0.72 & $0.16-0.58$ \\
Packers & 9 & 0.28 & $0.10-1.02$ \\
Forklift operators & 6 & 0.45 & 0.107 \\
Storagemen & 3 & 0.30 & $0.07-0.53$ \\
Machine operators & 2 & 0.47 & $0.37-0.58$ \\
Mechanical/electrical fitters & 3 & 0.44 & $0.09-0.85$ \\
Material testing workers & 4 & 0.20 & $0.12-0.31$ \\
Screw/railing workers & 3 & 0.33 & $0.06-0.81$ \\
\hline
\end{tabular}

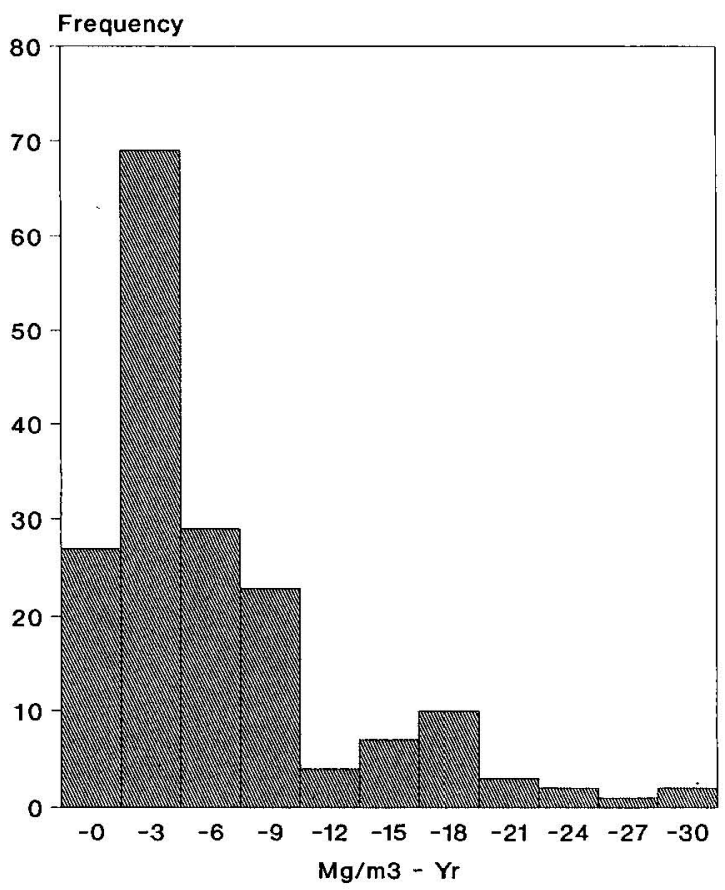

Figure 1. Distribution of cumulative dust exposure.

\section{Study populations}

All of the eligible 171 Chinese and Malay male workers aged 21 years and above and currently employed in production and maintenance work in these factories were studied. Since almost all of the workers were exposed to some degree of PVC dust, an external comparison group of unexposed workers was also studied at the same time. These were Chinese and Malay male workers, aged 21 years and above, with equivalent job titles such as drivers, mechanical workshop workers, electricians, and plumbers in three granite quarries (27 workers, $100 \%$ response) and in one hospital (21 workers, $87 \%$ response). The comparison workers in the quarries were exposed to low levels of silica (average $0.15 \mathrm{mg} / \mathrm{m}^{3}$ respirable granite dust).

A structured questionnaire was administered by trained field investigators to each worker, who provided his personal data, a detailed work history (including previous employment in other dusty occupations), information on previous medical history of tuberculosis, hypertensive heart diseases and so forth, smoking habits, and responses to the British Medical Research Council questionnaire on chronic bronchitis, as well as to additional questions on wheezing or chest tightness and atopy.

Spirometric testing was performed on a dry-wedged bellows spirometer (Vitalograph ${ }^{\circledR}$ ), which was regularly calibrated before use, on Monday mornings when workers began their shifts after a weekend off. Each subject performed maximal forced expiratory maneuvers in the standing position without a nose clip, and the best of three acceptable curves was used in deriving the forced vital capacity (FVC), forced expiratory volume in $1 \mathrm{~s}\left(\mathrm{FEV}_{1.0}\right)$, and the FEV \% [(100 $\left.\times \mathrm{FEV}_{1.0}\right) /$ FVC]. All of the values were corrected to body temperature and pressure saturation (BTPS). Height (to the nearest centimeter) and weight (to the nearest gram) was measured, the subject being without shoes and in light summer clothing.

Chest radiography was performed on the entire group of mixers (who were the most highly exposed to PVC dust) and subsamples of exposed nonmixers and unexposed referents. Since the mixers were a generally older group, the exposed nonmixers included other production and maintenance workers except those in the PVC railing and screw departments, who were mostly young workers. The external comparison group included only workers in the quarry, who were also comparable in age to the mixers. Postero-anterior radiographs of the chest were taken on high-quality largesized film and were then read independently and in random order by three readers, who were not aware of the exposure status of the subjects to which the radiographs belonged. The profusion of rounded and irregular small opacities was read, with reference to standard films, and according to the ILO International Standard Classification of Radiographs of Pneumoconiosis of 1980 . There was reasonably good reading agreement between the observers (appendix). 


\section{Analyses}

Since the observed respiratory effects were almost certainly the results of cumulative PVC dust exposure, which is a function of exposure intensity and duration, a cumulative dust exposure index was estimated for each PVC-exposed worker on the basis of information provided on the duration of employment for every job ever held in the factories. The current factory- and jobspecific dust concentration was assigned to each job held and multiplied by the duration in years and calculated as follows:

$$
\mathrm{C}=\Sigma \mathrm{K}_{\mathrm{j}} \cdot \mathrm{T}_{\mathrm{j}} \text {, }
$$

where $\mathrm{C}=$ the cumulative exposure index, $\mathrm{K}=$ the mean dust concentration $\left(\mathrm{mg} / \mathrm{m}^{3}\right), \mathrm{T}=$ exposure duration (years), and $\mathrm{j}=$ job category. It was recognized, however, that current measurements could not be assumed to reflect the previous dust exposure intensities accurately. Hence, the cumulative indices were only used to categorize workers into high and low cumulative exposure groups. This classification was done with the use of an arbitrary level of $10 \mathrm{mg} / \mathrm{m}^{3}$-years to separate those with high cumulative exposure from those with low (or average) exposure. Typically, those with a cumulative index higher than $10 \mathrm{mg} / \mathrm{m}^{3}$-years would represent a mixer exposed to an average PVC dust concentration of $1.0 \mathrm{mg} / \mathrm{m}^{3}$ for 10 or more years. The inclusion of, say, a packer typically exposed to $0.33 \mathrm{mg} / \mathrm{m}^{3}$ for 30 or more years was also allowed for. The distribution of the cumulative PVC dust exposure indices is shown in figure 1 . The unexposed group was assigned a nil cumulative exposure to PVC dust.

Comparisons of the lung function parameters between the exposed groups were performed by multiple regression techniques using general linear regression modeling procedures from the SAS (statistical analysis system) programs. The $\mathrm{FEV}_{1.0}, \mathrm{FVC}$, and FEV $\%$ were adjusted for age, height, cigarette-years, and race, entered as covariates in the models. The lung function parameters of the exposed groups were compared with those of the unexposed group with significance testing by an analysis of covariance. In addition, the lung function parameters of all the groups were compared with external population norms with the use of prediction equations for Singapore Chinese and Malay males $(11,12)$.
Radiological opacities were defined categorically as a profusion of small opacities of $0 / 1$ or greater, $1 / 0$ or greater, or $1 / 1$ or greater, as read by two or more of the three readers. Separate analyses of the prevalence of radiological opacities for each reader were also performed. Stratified analyses and the Cochran-Mantel-Haenszel test were used when the prevalences of radiological opacities were compared, and also when the prevalences of symptoms were compared by exposure groups with control for the influence of age ( $<45$ years, $\geq 45$ years) and smoking status (nonsmoker and ever smoker).

Thirteen workers with significant dust exposure from other previous occupations, one worker with previous pulmonary tuberculosis, one worker with hypertensive heart disease, and one worker with current respiratory tract infection were excluded from the analysis.

\section{Results}

Table 2 shows the mean age, height, and the proportions of each ethnic group and smokers by exposure group and table 3 the exposure characteristics of the groups. Multiple regression modeling showed both the $\mathrm{FEV}_{1.0}$ and FVC to be significantly related, in expected fashions, to age $(\mathrm{P}<0.001)$, height $(\mathrm{P}<0.0001)$, and cigarette-years $(P<0.01)$. Race was not a significant independent variable after adjustment for smoking in the model. $\mathrm{FEV}_{1.0}$ and FVC, after adjustment for the effects of these influencing variables, were both lower in the PVC-exposed groups (table 4). The percentage of predicted $\mathrm{FEV}_{1.0}$ and FVC in the unexposed group indicates that their lung volumes were comparable to the external population norms, whereas both $\mathrm{FEV}_{1.0}$ and FVC were about $4 \%$ lower in the low-exposure group and $7 \%$ lower in the high-exposure group.

The prevalence of respiratory symptoms among the exposure groups, after control for age and smoking, did not show any statistically significant differences except for frequencies of wheezing or chest tightness, which was greatest in the high-exposure group (table 5). Radiological small opacities, as read by at least two readers, with profusion $0 / 1$ and greater, age and smoking being controlled for, were significantly more frequent in the exposed groups in comparison with the

Table 2. Physical and smoking characteristics of the subjects by cumulative exposure group.

\begin{tabular}{|c|c|c|c|c|c|c|c|c|c|c|c|c|c|c|c|c|}
\hline \multirow{3}{*}{ Group } & \multicolumn{2}{|c|}{ Age years } & \multicolumn{2}{|c|}{ Height $(\mathrm{cm})$} & \multicolumn{4}{|c|}{ Race } & \multicolumn{8}{|c|}{ Smoking } \\
\hline & \multirow{2}{*}{ Mean } & \multirow{2}{*}{ SD } & \multirow{2}{*}{ Mean } & \multirow[t]{2}{*}{ SD } & \multicolumn{2}{|c|}{ Chinese } & \multicolumn{2}{|c|}{ Malay } & \multicolumn{2}{|c|}{$\begin{array}{c}\text { Non- } \\
\text { smoker }\end{array}$} & \multicolumn{2}{|c|}{$\begin{array}{c}\text { Ex- } \\
\text { smoker }\end{array}$} & \multicolumn{2}{|c|}{$\begin{array}{l}\text { Current } \\
\text { smoker }\end{array}$} & \multicolumn{2}{|c|}{$\begin{array}{l}\text { Cigarette- } \\
\text { years }\end{array}$} \\
\hline & & & & & $\mathrm{N}$ & $\%$ & $\mathbf{N}$ & $\%$ & $\mathbf{N}$ & $\%$ & $N$ & $\%$ & $\mathrm{~N}$ & $\%$ & Mean & SD \\
\hline $\begin{array}{l}\text { Unexposed }(N=48) \\
\text { Low exposure }\langle N=121)^{\mathrm{a}} \\
\text { High exposure }(N=34)^{\mathrm{b}}\end{array}$ & $\begin{array}{l}36.0 \\
35.2 \\
41.9\end{array}$ & $\begin{array}{l}12.7 \\
10.1 \\
8.77\end{array}$ & $\begin{array}{l}167.1 \\
167.1 \\
165.4\end{array}$ & $\begin{array}{l}5.6 \\
6.2 \\
5.3\end{array}$ & $\begin{array}{r}39 \\
102 \\
24\end{array}$ & $\begin{array}{l}81 \\
84 \\
71\end{array}$ & $\begin{array}{r}9 \\
19 \\
10\end{array}$ & $\begin{array}{l}19 \\
16 \\
29\end{array}$ & $\begin{array}{l}16 \\
63 \\
10\end{array}$ & $\begin{array}{l}33 \\
52 \\
29\end{array}$ & $\begin{array}{l}4 \\
6 \\
9\end{array}$ & $\begin{array}{c}8 \\
5 \\
26\end{array}$ & $\begin{array}{l}28 \\
52 \\
15\end{array}$ & $\begin{array}{l}58 \\
43 \\
44\end{array}$ & $\begin{array}{l}239 \\
105 \\
317\end{array}$ & $\begin{array}{l}377 \\
162 \\
404\end{array}$ \\
\hline
\end{tabular}

a $<10 \mathrm{mg} / \mathrm{m}^{3}$-years.

$\geq 10 \mathrm{mg} / \mathrm{m}^{3}$-years 
Table 3. Exposure characteristics of the subjects by cumulative exposure group. (PVC=polyvinyl chloride)

\begin{tabular}{|c|c|c|c|c|c|c|c|c|}
\hline \multirow{3}{*}{ Group } & \multirow{2}{*}{\multicolumn{2}{|c|}{$\begin{array}{l}\text { PVC cumulative } \\
\text { exposure }\end{array}$}} & \multirow{2}{*}{\multicolumn{2}{|c|}{$\begin{array}{l}\text { Years exposed } \\
\text { to PVC }\end{array}$}} & \multicolumn{4}{|c|}{ Job } \\
\hline & & & & & \multicolumn{2}{|c|}{ Mixers } & \multicolumn{2}{|c|}{$\begin{array}{l}\text { Exposed } \\
\text { nonmixers }\end{array}$} \\
\hline & Mean & SD & Mean & SD & $\mathbf{N}$ & $\%$ & $\mathrm{~N}$ & $\%$ \\
\hline Unexposed & - & $\cdot$ & - & $\cdot$ & $\cdots$ & $\cdots$ & . & . \\
\hline $\begin{array}{l}\text { Low exposure (<10 mg/m } / \mathrm{m}^{3} \text {-years) } \\
\text { High exposure }\left(\geq 10 \mathrm{mg} / \mathrm{m}^{3} \text {-years }\right)\end{array}$ & $\begin{array}{r}2.9 \\
18.0\end{array}$ & $\begin{array}{l}2.6 \\
5.5\end{array}$ & $\begin{array}{r}7.5 \\
14.7\end{array}$ & $\begin{array}{l}6.2 \\
4.2\end{array}$ & $\begin{array}{r}9 \\
30\end{array}$ & $\begin{array}{r}7.4 \\
88.2\end{array}$ & $\begin{array}{r}112 \\
4\end{array}$ & $\begin{array}{l}92.6 \\
11.8\end{array}$ \\
\hline
\end{tabular}

Table 4. Lung functions by exposure group. $\left[\mathrm{FEV}_{1.0}=\right.$ forced expiratory volume in $1 \mathrm{~s}, \mathrm{FVC}=$ forced vital capacity, $\mathrm{FEV} \%=$ $\left.\left(100 \cdot \mathrm{FEV}_{1.0}\right) / \mathrm{FVC}\right]$

\begin{tabular}{|c|c|c|c|c|c|c|c|c|c|c|}
\hline \multirow{2}{*}{ Group } & \multicolumn{2}{|c|}{$\mathrm{FEV}_{1.0}(\mathrm{l})^{\mathrm{a}}$} & \multicolumn{2}{|c|}{ FVC $(I)^{a}$} & \multicolumn{2}{|c|}{$\begin{array}{c}\mathrm{FEV}_{1,0} \\
(\% \text { of predicted })^{\mathrm{b}}\end{array}$} & \multicolumn{2}{|c|}{ 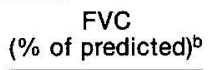 } & \multicolumn{2}{|c|}{ FEV\% ${ }^{b}$} \\
\hline & Mean & SD & Mean & SD & Mean & SD & Mean & SD & Mean & SD \\
\hline $\begin{array}{l}\text { Unexposed } \\
\text { Low exposure ( }<10 \mathrm{mg} / \mathrm{m}^{3} \text {-years) } \\
\text { High exposure ( } \geq 10 \mathrm{mg} / \mathrm{m}^{3} \text {-years) }\end{array}$ & $\begin{array}{l}3.13 \\
3.03 \\
2.93\end{array}$ & $\begin{array}{l}0.41 \\
0.44 \\
0.41^{* *}\end{array}$ & $\begin{array}{l}3.64 \\
3.47 \\
3.39\end{array}$ & $\begin{array}{l}0.48 \\
0.53 \\
0.47^{*}\end{array}$ & $\begin{array}{l}99.3 \\
96.4 \\
92.7\end{array}$ & $\begin{array}{l}12.2 \\
12.3 \\
12.4^{* *}\end{array}$ & $\begin{array}{l}99.4 \\
95.1 \\
92.3\end{array}$ & $\begin{array}{l}11.8 \\
11.9 \\
12.0^{\star *}\end{array}$ & $\begin{array}{l}86.3 \\
87.4 \\
86.5\end{array}$ & $\begin{array}{l}6.2 \\
6.2 \\
6.3\end{array}$ \\
\hline
\end{tabular}

a Adjusted for age, height, race, cigarette-years.

b Adjusted for cigarette-years.

${ }^{*} P<0.05,{ }^{* *} P<0.01$ (analysis of covariance).

Table 5. Respiratory symptom prevalence by exposure group.

\begin{tabular}{|c|c|c|c|c|c|c|}
\hline \multirow{2}{*}{ Symptom } & \multicolumn{2}{|c|}{ Unexposed } & \multicolumn{2}{|c|}{$\begin{array}{c}\text { Low exposure } \\
\text { (<10 mg/m } 3 \text {-years) } \\
\end{array}$} & \multicolumn{2}{|c|}{$\begin{array}{c}\text { High exposure } \\
\left(\geq 10 \mathrm{mg} / \mathrm{m}^{3} \text {-years }\right)\end{array}$} \\
\hline & $\mathbf{N}$ & $\%$ & $\mathbf{N}$ & $\%$ & $N$ & $\%$ \\
\hline \multicolumn{7}{|l|}{ Cough } \\
\hline $\begin{array}{l}\text { Morning } \\
\text { Day or night } \\
\text { Three months in year }\end{array}$ & $\begin{array}{l}5 \\
8 \\
3\end{array}$ & $\begin{array}{r}10.2 \\
16.3 \\
6.1\end{array}$ & $\begin{array}{r}11 \\
7 \\
6\end{array}$ & $\begin{array}{l}9.1 \\
5.8 \\
5.0\end{array}$ & $\begin{array}{l}6 \\
5 \\
4\end{array}$ & $\begin{array}{l}17.6 \\
14.7 \\
11.8\end{array}$ \\
\hline \multicolumn{7}{|l|}{ Phlegm } \\
\hline $\begin{array}{l}\text { Morning } \\
\text { Day or night } \\
\text { Three months in year }\end{array}$ & $\begin{array}{l}8 \\
9 \\
8\end{array}$ & $\begin{array}{l}16.3 \\
18.4 \\
16.3\end{array}$ & $\begin{array}{l}22 \\
13 \\
14\end{array}$ & $\begin{array}{l}18.2 \\
10.7 \\
11.6\end{array}$ & $\begin{array}{l}8 \\
6 \\
6\end{array}$ & $\begin{array}{l}23.5 \\
17.6 \\
17.6\end{array}$ \\
\hline Periods of cough and phlegm & 3 & 6.1 & 1 & 0.8 & - & 0.0 \\
\hline Breathlessness & 10 & 20.8 & 22 & 18.2 & 6 & 17.6 \\
\hline Wheezing/chest tightness & 2 & 4.1 & 10 & 8.3 & 8 & 23.5 \\
\hline
\end{tabular}

* $P<0.01$ (Cochran-Mantel-Haenszel test of general association controlling for age and cigarette smoking).

unexposed group (table 6). Stratified analyses showed that age, but not smoking, was significantly associated with radiological small opacities with profusion $\geq 0 / 1$ (at least two readers).

Altogether 17 persons had small opacities of profusion $1 / 0$ and greater in their radiographs, as read by at least two readers. Four persons had radiological profusion $1 / 1$, and one had $1 / 2$ profusion. No one in the unexposed group had radiological profusion greater than 1/0. There was a twofold higher prevalence of radiological opacities of profusion $1 / 0$ or greater in the high-exposure group as compared with the low-exposure group. Radiological small opacities of profusion 1/1 and greater were seen only in the highexposure group.
Similar results were obtained when the radiographic readings for each reader were used in the analyses. The predominant types of opacities were irregular although the readers differed in their interpretation, particularly with respect to the shape but not the size of the opacities (which were all read as $<0.5 \mathrm{~mm}$ in diameter). Reader one read mostly irregular opacities, reader two read more irregular than rounded opacities, and reader three read more rounded than irregular opacities (table 7).

\section{Discussion}

In a cross-sectional study, the reference group is the most appropriately chosen from within the same fac- 
Table 6. Prevalence of radiological opacities by reader and exposure group.

\begin{tabular}{|c|c|c|c|c|c|c|}
\hline \multirow{2}{*}{ Parameters } & \multicolumn{2}{|c|}{$\begin{array}{l}\text { Unexposed }^{a} \\
(\mathrm{~N}=27)\end{array}$} & \multicolumn{2}{|c|}{$\begin{array}{l}\text { Low exposure }{ }^{b} \\
(N=81)\end{array}$} & \multicolumn{2}{|c|}{$\begin{array}{l}\text { High exposurec } \\
\quad(\mathrm{N}=29)\end{array}$} \\
\hline & $\mathrm{N}$ & $\%$ & $\mathrm{~N}$ & $\%$ & $\mathrm{~N}$ & $\%$ \\
\hline \multicolumn{7}{|l|}{ Reader 1} \\
\hline $\begin{array}{l}\text { Profusion } \geq 0 / 1 \\
\text { Profusion } \geq 1 / 0 \\
\text { Profusion } \geq 1 / 1\end{array}$ & $\begin{array}{l}7 \\
1 \\
1\end{array}$ & $\begin{array}{r}25.9 \\
3.7 \\
3.7\end{array}$ & $\begin{array}{l}49 \\
13 \\
-\end{array}$ & $\begin{array}{r}60.5 \\
16.0 \\
0.0\end{array}$ & $\begin{array}{r}21 \\
8 \\
4\end{array}$ & $\begin{array}{l}72.4^{*} \\
27.6^{*} \\
13.8^{*}\end{array}$ \\
\hline \multicolumn{7}{|l|}{ Reader 2} \\
\hline $\begin{array}{l}\text { Profusion } \geq 0 / 1 \\
\text { Profusion } \geq 1 / 0 \\
\text { Profusion } \geq 1 / 0\end{array}$ & $\frac{4}{-}$ & $\begin{array}{r}14.8 \\
0.0 \\
0.0\end{array}$ & $\begin{array}{l}38 \\
12 \\
-\end{array}$ & $\begin{array}{r}46.9 \\
14.8 \\
0.0\end{array}$ & $\begin{array}{r}16 \\
8 \\
4\end{array}$ & $\begin{array}{l}55.2^{*} \\
27.6^{*} \\
13.8^{* *}\end{array}$ \\
\hline \multicolumn{7}{|l|}{ Reader 3} \\
\hline $\begin{array}{l}\text { Profusion } \geq 0 / 1 \\
\text { Profusion } \geq 1 / 0 \\
\text { Profusion } \geq 1 / 1\end{array}$ & $\frac{4}{-}$ & $\begin{array}{r}14.8 \\
0.0 \\
0.0\end{array}$ & $\begin{array}{r}32 \\
14 \\
8\end{array}$ & $\begin{array}{r}39.5 \\
17.3 \\
9.9\end{array}$ & $\begin{array}{r}13 \\
7 \\
6\end{array}$ & $\begin{array}{l}44.8^{*} \\
24.1^{*} \\
20.1^{* *}\end{array}$ \\
\hline \multicolumn{7}{|c|}{ Two or more readers } \\
\hline $\begin{array}{l}\text { Profusion } \geq 0 / 1 \\
\text { Profusion } \geq 1 / 0 \\
\text { Profusion } \geq 1 / 1\end{array}$ & $\frac{4}{-}$ & $\begin{array}{r}14.8 \\
0.0 \\
0.0\end{array}$ & $\begin{array}{l}37 \\
10 \\
-\end{array}$ & $\begin{array}{r}45.7 \\
12.3 \\
0.0\end{array}$ & $\begin{array}{r}16 \\
7 \\
5\end{array}$ & $\begin{array}{l}55.2^{\star} \\
24.1^{\star} \\
17.2^{\star *}\end{array}$ \\
\hline
\end{tabular}

a Mean age of the group 41.1 (SD 12.4) years with seven (26\%) nonsmokers, three (11\%) ex-smokers, and 17 (63\%) current smokers.

b Low exposure $=<10 \mathrm{mg} / \mathrm{m}^{3}$-years; mean age of the group 35.2 (SD 10.3) years with $60(50 \%)$ nonsmokers, seven $(6 \%)$ exsmokers, and $53(44 \%)$ current smokers.

c High exposure $=\geq 10 \mathrm{mg} / \mathrm{m}^{3}$-years; mean age of the group 41.0 (SD 9.1) years with nine (26\%) nonsmokers, nine (26\%) exsmokers, and $16(47 \%)$ current smokers.

* $\mathrm{P} \leq 0.05,{ }^{\star *} \mathrm{P}<0.01$ (Cochran-Mantel-Haenszel test of general association, controlling for age and smoking status).

Table 7. Distribution of radiological types by reader and exposure group.

\begin{tabular}{|c|c|c|c|c|c|c|}
\hline & \multicolumn{2}{|c|}{ Unexposed } & \multicolumn{2}{|c|}{$\begin{array}{c}\text { Low exposure } \\
\left(<10 \mathrm{mg}^{3} \mathrm{~m}^{3} \text {-years }\right)\end{array}$} & \multicolumn{2}{|c|}{$\begin{array}{c}\text { High exposure } \\
\left(\geq 10 \mathrm{mg} / \mathrm{m}^{3} \text {-years }\right)\end{array}$} \\
\hline & Rounded & Irregular & Rounded & Irregular & Rounded & Irregular \\
\hline \multicolumn{7}{|l|}{ Reader 1} \\
\hline $\begin{array}{l}\text { Profusion } \geq 0 / 1 \\
\text { Profusion } \geq 1 / 0 \\
\text { Profusion } \geq 1 / 1\end{array}$ & $\frac{3}{-}$ & $\begin{array}{l}4 \\
1 \\
1\end{array}$ & $\begin{array}{l}- \\
-\end{array}$ & $\begin{array}{l}49 \\
13 \\
-\end{array}$ & $\begin{array}{l}- \\
-\end{array}$ & $\begin{array}{r}21 \\
8 \\
4\end{array}$ \\
\hline \multicolumn{7}{|l|}{ Reader } \\
\hline $\begin{array}{l}\text { Profusion } \geq 0 / 1 \\
\text { Profusion } \geq 1 / 0 \\
\text { Profusion } \geq 1 / 1\end{array}$ & $\frac{3}{-}$ & $\frac{1}{-}$ & $\begin{array}{r}11 \\
4 \\
-\end{array}$ & $\begin{array}{r}27 \\
8 \\
-\end{array}$ & $\begin{array}{l}8 \\
5 \\
3\end{array}$ & $\begin{array}{l}8 \\
3 \\
1\end{array}$ \\
\hline \multicolumn{7}{|l|}{ Reader 3} \\
\hline $\begin{array}{l}\text { Profusion } \geq 0 / 1 \\
\text { Profusion } \geq 1 / 0 \\
\text { Profusion } \geq 1 / 1\end{array}$ & $\frac{3}{-}$ & $\frac{1}{-}$ & $\begin{array}{r}24 \\
10 \\
5\end{array}$ & $\begin{array}{l}8 \\
4 \\
3\end{array}$ & $\begin{array}{l}9 \\
5 \\
4\end{array}$ & $\begin{array}{l}4 \\
2 \\
2\end{array}$ \\
\hline
\end{tabular}

tory if it is certain that it is indeed unexposed. Our environmental assessment clearly indicated a secondary exposure in the ambient air for almost all of the workers in these factories; and this secondary exposure was likely in itself to produce some degree of pulmonary effects. It was therefore necessary to choose an external comparison group, which we believed was appropriate for the study since it was an occupational counterpart in other industrial undertakings. The validity of this group was well supported externally by the good approximation of their lung functions to predicted norms from other independent population samples.

The previous dust levels in the factories were not known, but there were reasons to suppose that they were probably higher than current levels. Since only current dust levels were known, it should be emphasized that the estimates of cumulative PVC dust exposure were not based on actual dust exposure levels. The data in this study were, therefore, used only for categorizing broad groups of PVC-exposed subjects and not for deriving quantitative exposure-response relationships.

Exogenous sources of VCM and thermal decomposition products may be ruled out as the cause of the observed pulmonary effects since VCM exposure from residues in the PVC powder was negligible and irritant and toxic gases like hydrochloric acid, VCM, phosgene, and chlorine are only formed at temperatures in excess of $225^{\circ} \mathrm{C}$. We also made measurements 
at the mixer and extruder, and hydrochloric acid and VCM were not detectable. However, it is more difficult to exclude the possibility that the radiological opacities could also have resulted from additives containing radio-dense calcium and barium compounds in the mixture, although only small quantities of these substances were used.

The radiological readings were all done by physicians experienced in the assessment of radiographs for pneumoconiosis, and standard guidelines were used under controlled conditions so as to eliminate subjective bias and produce unequivocal case identification. Under the circumstances, the effects of aging and cigarette smoking were unlikely to produce radiological opacities more profuse than category $1 / 0$. There should therefore be little if any doubt that at least radiological profusion $1 / 1$ in five workers indeed represented PVC pneumoconiosis.

Both diffuse micronodular and linear-reticular opacities have been described in case reports of PVC pneumoconiosis, characterized histopathologically as pulmonary fibrosis associated with granulomatous lesions $(1,13)$. Similar histological changes were observed in experimental studies with guinea pigs and rats $(14,15)$. As in previous epidemiologic studies $(3,5$, 7), the present study indicated that the radiological lesions arising from PVC dust exposure were of limited profusions with a predominance of irregular small opacities. The reported prevalence of radiological lesions varied greatly among the studies. It is, however, difficult to make valid comparisons among the studies because of differences in procedures and criteria for radiological case definition, although in two of the studies, ILO standard films and radiological classification were employed for reading by a minimum of two or three readers $(5,7)$. Furthermore, the prevalence of radiological small opacities may be expected to vary with the level of PVC dust exposure, but such measurements were only performed in one study (6). In the study by Soutar et al (6), the estimated dust index of $14 \mathrm{mg} / \mathrm{m}^{3}$-years appeared to be comparable to that of the high-exposure group in our study, but in both studies, past levels of PVC dust exposure was unknown.

Previous reports of an association between PVC exposure and a restrictive type of lung function impairment $(2,3,6)$ was supported by the findings of the present study. The average lung function loss was modest, but, given individual variation in responses to PVC exposure, a few persons in any exposed population may be expected to experience clinically significant lung function impairment. PVC exposure was also found to be associated with an increased prevalence of dyspnea in the study by Soutar et al (6). No such association was demonstrated in our study, but it should be noted that, whereas the study by Soutar et al included past workers, we could only study current workers who might probably be overrepresented by those whose functional impairment was not severe enough to prevent them from continuing with their current employment. We did, however, find an increased prevalence of wheezing or chest tightness, and such findings have not been reported in previous studies. Apparently, responses to these symptoms were never elicited in previous studies. The possibility of reversible airway obstruction, however, corroborates with the results of a recent study showing across-shift $\mathrm{FEV}_{1.0}$ changes in PVC fabrication workers (9), and a recent report of bronchial asthma from inhalational provocation tests with PVC dust (16), and should therefore be further investigated.

\section{Acknowledgments}

This study was conducted with research grant RP880371 from the National University of Singapore and the support and assistance of the Singapore AntiTuberculosis Association. We also wish to thank Dr Moozoomdar for his interest and special assistance, and the Permanent Secretary of the Ministry of Labour for permission to publish this report.

\section{References}

1. Szende B, Lapis K, Nemes A, Pinter A. Pneumoconiosis caused by the inhalation of polyvinyl chloride dust. Med Lav 1970;61:433-6

2. Miller A, Teirstein AS, Chuang M, Selikoff I. Changes in pulmonary function in workers exposed to vinyl chloride and polyvinyl chloride. Ann NY Acad Sci 1975; 246:42-52.

3. Lillis R, Anderson H, Miller A, Selikoff I. Pulmonary changes among vinyl chloride polymerization workers. Chest 1976;2:299-305.

4. Gamble J, Liu S, McMichael AJ, Waxweiler R. Effects of occupational and non-occupational factors on the respiratory system of vinyl chloride and other workers. J Occup Med 1975;18:659-70.

5. Mastrangello CT, Manno M, Marcer G, et al. Polyvinyl chloride pneumoconiosis: epidemiological study of exposed workers. J Occup Med 1979;21:540-2.

6. Soutar CA, Copland LA, Thornley PE, et al. Epidemiological study of respiratory disease in workers exposed to polyvinylchloride dust. Thorax 1983;35:644-52.

7. Chivers CR, Lawrence-Jones C, Paddle GM. Lung function in workers exposed to polyvinyl chloride dust. $\mathrm{Br}$ J Ind Med 1978;37:147-51.

8. Baser M, Tockman MS, Kennedy TP. Pulmonary function and respiratory symptoms in polyvinylchloride fabrication workers. Am Rev Respir Dis 1985;131(2): 203-8.

9. Ernst P, De Guire L, Armstrong B, Theriault G. Obstructive and restrictive ventilatory impairment in polyvinylchloride fabrication workers. Am J Ind Med 1988; 14:273-9.

10. Prodan L, Suciu I, Pislaru V, Ilea E, Pascu L. Experimental chronic poisoning with vinyl chloride (monochloroethene). Ann NY Acad Sci 1975;246:159-63.

11. Da Costa JL, Goh BK. Prediction normograms for lung function measurements in adult Chinese. Singapore Med J 1971;12,4:193-8.

12. Zee KO. Ventilatory function in normal industrial workers in Singapore. Ann Acad Med Singapore 1977;6 (suppl):587-95.

13. Arnaud A, Pommier de Santi P, Garbe L, Payan H, 
Charpin J. Polyvinyl chloride pneumoconiosis. Thorax 1978;33:19-25.

14. Frongia N, Spinazzola A, Bucarelli A. Experimental pulmonary lesions from prolonged inhalations of PVC dust in a work environment. Med Lav 1974;65:321-42.

15. Agarwal DK, Kaw JL, Srivastava SP, Seth PK. Some biochemical and histopathological changes induced by polyvinylchloride dust in rat lung. Environ Res 1978; 16:333-41.

16. Lee HS, Yap J, Wang YT, Lee CS, Tan KT, Poh SC. Occupational asthma due to unheated polyvinylchloride resin dust. Br J Ind Med 1989;46:820-2.

\section{Appendix}

Agreement between the readers of the radiographs

\begin{tabular}{lcrllll}
\hline \multirow{2}{*}{ Reader 2} & \multicolumn{7}{c}{ Reader 1} \\
\cline { 2 - 7 } & $0 /-$ & $0 / 0$ & $0 / 1$ & $1 / 0$ & $1 / 1$ & $1 / 2$ \\
\hline $0 / 1-$ & - & 8 & - & - & - & - \\
$0 / 0$ & - & 48 & 21 & 2 & - & - \\
$0 / 1$ & - & 4 & 24 & 9 & 1 & - \\
$1 / 0$ & - & - & 10 & 5 & 1 & - \\
$1 / 1$ & - & - & - & 1 & 2 & - \\
$1 / 2$ & - & - & - & - & - & 1 \\
\hline
\end{tabular}

Kendall's tau-B 0.637 (SE 0.041)

\begin{tabular}{lcrrrrr}
\hline \multirow{2}{*}{ Reader 3 } & \multicolumn{7}{c}{ Reader 1 } \\
\cline { 2 - 7 } & $0 /-$ & $0 / 0$ & $0 / 1$ & $1 / 0$ & $1 / 1$ & $1 / 2$ \\
\hline $0 /-$ & - & - & - & - & - & - \\
$0 / 0$ & - & 55 & 30 & 3 & - & - \\
$0 / 1$ & - & 5 & 17 & 5 & 1 & - \\
$1 / 0$ & - & - & 5 & 2 & 0 & - \\
$1 / 1$ & - & - & 3 & 7 & 3 & - \\
$1 / 2$ & - & - & - & - & - & 1 \\
\hline
\end{tabular}

Kendall's tau-B 0.574 (SE 0.054)

\begin{tabular}{lcrrrrr}
\hline \multirow{7}{*}{ Reader 3 } & \multicolumn{7}{c}{ Reader 2} \\
\cline { 2 - 7 } & $0 /-$ & $0 / 0$ & $0 / 1$ & $1 / 0$ & $1 / 1$ & $1 / 2$ \\
\hline $0 /-$ & - & - & - & - & - & - \\
$0 / 0$ & - & 63 & 14 & 3 & - & - \\
$0 / 1$ & - & 7 & 18 & 2 & - & - \\
$1 / 0$ & - & - & 2 & 8 & 3 & - \\
$1 / 1$ & - & - & - & - & - & 1 \\
$1 / 2$ & & &
\end{tabular}

Kendall's tau-B 0.632 (SE 0.054)

Received for publication: 9 May 1990 